\title{
Analisis Karakteristik Kemampuan Guru Matematika SMP Melaksanakan Pembelajaran Berbasis Kurikulum 2013 di Kota Palu
}

\author{
Welli Meinarni' ${ }^{1)}$, Usman HB. ${ }^{2)}$, Pathuddin ${ }^{3)}$ \\ Pendidikan Matematika, Universitas Tadulako ${ }^{1)}$ \\ Wellimeinarni91@gmail.com ${ }^{l)}$,usmanhjbeddu@gmail.com ${ }^{2)}$,Pathuddin@yahoo.com ${ }^{3)}$
}

\begin{abstract}
Abstrak: Tujuan penelitian ini adalah untuk mendeskripsikan secara rinci karakteristik kemampuan guru dalam melaksanakan pembelajaran berbasis kurikulum 2013. Kemampuan guru dalam melakukan pembelajaran berbasis kurikulum 2013 difokuskan pada proses pembelajaran divergen dan konvergen. Subjek dalam penelitian ini adalah guru matematika yang sudah berpengalaman dan guru pemula di Kota Palu. Teknik pengambilan subjek penelitian ini menggunakan purposive sampling, karena banyaknya subjek penelitian tergantung pada keadaan data dari lapangan. Pengumpulan data dilakukan dengan cara merekam pelaksanaan pembelejaran di kelas yang berbasis kurikulum 2013. Berdasarkan hasil observasi pada dokumentasi tersebut, lalu subjek penelitian diwawancara secara mendalam untuk mengungkap karakteristik kemampuan guru dalam melaksanakan pembelajaran berbasis kurikulum 2013. Hasil wawancara didokumentasikan dengan menggunakan handycam, voice record, dan kamera digital. Untuk menentukan kredibilitas data dilakukan beberapa hal, yaitu (1) dilakukan uji triangulasi, (2) mengadakan member-check, (3) meningkatkan ketekunan dan perpanjangan pengamatan. Hasil penelitian menunjukkan bahwa sebagian besar guru belum mampu melaksanakan pembelajaran yang sesuai dengan kurikulum 2013. Peneliti juga mengungkapkan bahwa karakteristik kemampuan guru dalam melakukan pembelajaran berbasis kurikulum 2013 lebih menekankan pada proses pembelajaran konvergen dibandingkan divergen.
\end{abstract}

Kata Kunci: Karakteristik Kemampuan Guru, Guru Matematika SMP, Kurikulum 2013

Pemerintah terus berusaha untuk memperbaiki sistem pendidikan yang ada di Indonesia. Salah satu usaha yang dilakukan yaitu dengan menerapkan kurikulum 2013. Sebelumnya, kurikulum yang diterapkan adalah Kurikulum Tingkat Satuan Pendidikan (KTSP). Perubahan kurikulum ini bertujuan untuk memperbaharui kurikulum menjadi lebih baik. Kurikulum 2013 menganut pandangan dasar bahwa pengetahuan tidak dapat dipindahkan begitu saja dari guru ke peserta didik. Peserta didik secara aktif mencari, mengolah, membangun, dan menggunakan pengetahuan. Untuk itu pembelajaran harus berkenaan dengan kesempatan yang diberikan kepada peserta didik untuk mengkonstruksi pengetahuan dalam proses kognitifnya.

Implementasi Kurikulum 2013 dalam proses pembelajaran disarankan untuk menggunakan pendekatan saintifik, pembelajaran berbasis masalah, atau pembelajaran berbasis proyek (Menteri Pendidikan dan Kebudayaan, 2013). Berdasarkan Permendikbud Nomor 81A Tahun 2013 tentang Implementasi Kurikulum lampiran IV dinyatakan bahwa pendekatan yang direkomendasikan untuk diterapkan adalah pendekatan saintifik. Pembelajaran saintifik dapat didefinisikan sebagai pembelajaran yang dirancang sedemikian rupa sehingga peserta didik secara aktif mengkonstruk konsep, hukum, atau prinsip melalui langkah-langkah mengamati, merumuskan pertanyaan, mengumpulkan data atau informasi, menganalisis data, menarik kesimpulan, dan mengkomunikasikan kesimpulan (Mulyani: 2013).

Pendekatan saintifik diimplementasikan sesuai dengan karakteristik mata pelajaran. Dalam pembelajaran matematika, pendekatan saintifik dapat membantu merasionalkan 
materi pelajaran kepada peserta didik. Sesuai dengan salah satu karakteristik pendekatan saintifik yaitu keterampilan proses sains dan membangun konsep. Hal yang abstrak dalam matematika dapat lebih mudah diubah menjadi sesuatu yang lebih riil dalam konteks yang telah diketahui oleh peserta didik sebelumnya. Pembelajaran seperti ini dimaksudkan untuk meningkatkan dan membentuk sikap, keterampilan, dan pengetahuan peserta didik secara maksimal.

Menurut Shuhua, Kulm, \& Wu (2004), pembelajaran dapat dilihat sebagai proses divergen dan konvergen. Proses divergen pada pembelajaran yaitu berdasarkan pada isi dan pengetahuan kurikulum tanpa fokus dan mengabaikan pemikiran matematika peserta didik, sedangkan proses konvergen pada pembelajaran fokus pada pemikiran matematika peserta didik, yang terdiri dari empat aspek, yaitu membangun ide matematika, mengatasi kesalahapahaman peserta didik, melibatkan peserta didik dalam pembelajaran matematika, dan meningkatkan pemikiran peserta didik secara matematis.

Keberhasilan proses pembelajaran yang berbasis kurikulum 2013 tidak terlepas dari peran guru. Menurut Machali (2014), "kurikulum menjadi penuntun (guide) para pelaksana pendidikan-pendidik, tenaga kependidikan-untuk mengembangkan kreativitas dan kemampuannya dalam mengembangkan dan menjabarkan berbagai materi dan perangkat pembelajaran. Ini artinya, perubahan kurikulum mengusik kemampuan guru dalam merencanakan dan melaksanakan pembelajaran yang sesuai dengan prinsip-prinsip kurikulum 2013. Peran guru memang sangat penting dalam menentukan keberhasilan implementasi setiap inovasi di dunia pendidikan. Sanders, Wright, \& Horn (1997) menjelaskan:

"... the most important factor affecting student learning is the teacher. The immediate and clear implication of this finding is that seemingly more can be done to improve education by improving the effectness of teachers than by any other single factor. Effective teachers appear to be effective with students of all achievement levels, regardless of the level heterogenity in their calssrooms".

Kurikulum baru menuntut guru untuk memiliki kemampuan mengembangkan kurikulum serta proses pembelajaran yang dilakukan di dalam kelas. Kurikulum 2013 sudah diterapkan beberapa tahun yang lalu, tetapi masih banyak masalah yang terjadi terkait implementasinya di lapangan. Wawancara informal peneliti terhadap beberapa guru matematika yang sedang melanjutkan pendidikan magister di Universitas Tadulako menunjukkan bahwa belum semua guru memahami prinsip-prinsip pembelajaran pada kurikulum 2013 dan mengalami kesulitan ketika mengimplementasikannya di dalam kelas.

Hasil penelitian yang dilakukan oleh Muliatina (2016), yaitu sebagian guru masih teringat dengan pendekatan yang lama yang biasa digunakan pada saat masih berlaku kurikulum KTSP, guru mengatakan pada saat mengajar masih sering tercampur-campur antara pendekatan yang lama dengan pendekatan saintifik yang digunakan sekarang. Guru juga mengalami kesulitan dalam melaksanakan komponen-komponen yang ada dalam pendekatan saintifik.

Menurut Ningsih, Koryati, \& Deskoni (2016), kesulitan guru dalam pembelajaran saintifik masuk dalam kategori cukup sulit dalam kegiatan mencipta atau mengumpulkan informasi. Kesulitan lainnya yang juga dialami guru dalam menerapkan pendekatan saintifik yang pada dasarnya menekankan keterampilan proses antara lain waktu yang terbatas, kesulitan anak dalam menggunakan alat dan menarik kesimpulan dari sebuah eksperimen, peserta didik yang kurang aktif, dan kebiasaan peserta didik yang memperoleh pengetahuan dari penjelasan guru (teacher oriented) (Wardani dan Budiharti, 2014). 
Berdasarkan hasil penelitian yang telah dilakukan oleh beberapa peneliti dapat diketahui bahwa kemampuan yang dimiliki oleh seetiap guru dalam implementasi tidaklah sama. Oleh karena itu, peneliti akan melakukan penelitian tentang analisis karakteristik

kemampuan guru matematika SMP melaksanakan pembelajaran berbasis kurikulum 2013 di Kota Palu.

\section{METODE PENELITIAN}

Tujuan dari penelitian ini adalah untuk menganalisis secara mendalam tentang karakteristik kemampuan guru matematika melaksanakan pembelajaran di kelas berbasis kurikulum 2013 di Kota Palu. Oleh karena itu, jenis penelitian yang digunakan dalam penelitian ini adalah penelitian kualitatif.

Subjek dalam penelitian ini adalah guru matematika SMP yang berpengalaman dan guru matematika SMP pemula di Kota Palu. Penelitian ini menggunakan pendekatan kualitatif, maka banyak subjek penelitian sangat tergantung keadaan data dari lapangan. Dengan demikian, cara pengambilan subjek penelitian ini menggunakan purposive sampling.

Pengumpulan data dilakukan dengan cara merekam pelaksanaan pembelejaran di kelas yang berbasis kurikulum 2013. Berdasarkan hasil observasi pada dokumentasi tersebut, lalu subjek penelitian diwawancara secara mendalam untuk mengungkap karakteristik kemampuan guru dalam melaksanakan pembelajaran berbasis kurikulum 2013. Hasil wawancara didokumentasikan dengan menggunakan handycam, voice record, dan kamera digital. Untuk menentukan kredibilitas data dilakukan beberapa hal, yaitu (1) dilakukan uji triangulasi, (2) mengadakan member-check, (3) meningkatkan ketekunan dan perpanjangan pengamatan.

\section{HASIL PENELITIAN}

\section{Subjek dan Karakter Subjek Penelitian}

Setelah melalui proses pemilihan subjek penelitian, terpilih empat guru matematika untuk menjadi subjek penelitian. Dua orang guru termasuk dalam kategori guru yang telah berpengalaman dan dua orang guru termasuk dalam kategori guru pemula. Karakter guru yang berpengalaman dalam penelitian ini adalah guru yang telah memiliki pengalaman mengajar di atas 20 tahun. Guru dengan pengalaman mengajar kurang dari 5 tahun dan merupakan guru-guru muda merupakan karakter dari guru pemula.

Oleh karena penelitian ini adalah penelitian kualitatif studi kasus yang tujuannya untuk mendeskripsikan karakter kemampuan guru matematika SMP dalam melaksanakan pembelajaran berbasis kurikulum 2013, maka dimungkinkan memilih subjek yang heterogen. Melalui karakter tersebut, data kedua subjek penelitian akan melengkapi satu sama lain, sehingga memungkinkan untuk mendeskripsikan lebih dalam. Berikut akan disajikan kode-kode dari subjek penelitian untuk mempermudah dalam menyebutkannya pada bagian pembahsan.

Tabel 1 Kode Subjek Penelitian 


\begin{tabular}{cll}
\hline Guru Pengalaman & GS1 & GS2 \\
\hline Guru Pemula & GP1 & GP2 \\
\hline
\end{tabular}

\section{Hasil Pemeriksaan Kredibilitas Data}

Data utama dalam penelitian ini adalah data wawancara. Data ini akan dianalisis menggunakan analisis isi kualitatif untuk menjawab pertanyaan penelitian. Sebelum dilakukan analisis terhadap data tersebut, terlebih dahulu diperiksa kredibilitas tiap-tiap data. Pemeriksaan kredibilitas data dilakukan dengan cara meminta subjek penelitian untuk memeriksa kesesuaian data yang telah dikumpulkan oleh peneliti. Karena tujuan penelitian ini adalah untuk memahami karakteristik kemampuan guru matematika SMP melaksanakan pembelajaran berbasis kurikulum 2013 dan yang menjadi subjek penelitian adalah guru matematika, serta wawancara terhadap subjek penelitian dilakukan dengan bebas (tanpa tekanan), maka kredibilitas data dijamin aman (Stenbacka, 2001).

\section{Hasil Analisi Data Penelitian}

Analisis isi kualitatif dilakukan dengan skema koding sebagai alat mengoding data yang merupakan inti analisis isi kualitatif. Skema koding yang digunakan dalam mengawali analisis ini terdiri atas 2 kategori utama. Adapun kategori-kategori tersebut, yaitu (1) pembelajaran divergen, dan (2) pembelajaran konvergen. Setelah proses analisis berlangsung sejumlah data yang relevan dengan fokus penelitian tidak/kurang bersesuaian dengan kategori yang ada dalam skema koding. Sehingga, untuk melengkapi skema koding yang ada, sejumlah sub-sub kategori baru dibangkitkan yang bersesuaian dengan data yang ditemukan.

Hasil analisis isi kualitatif yang akan dipaparkan pada bagian berikut ini disajikan menurut kategori-kategori dan sub-sub kategori yang tercakup di dalamnya.

Tabel 2 Kategori dan sub-sub kategori yang dibangkitkan dari data

\begin{tabular}{lll}
\hline \multicolumn{1}{c}{ Kategori } & \multicolumn{1}{c}{ Sub-kategori } & Karakteristik \\
\hline $\begin{array}{l}\text { Pembelajaran } \\
\text { Divergen }\end{array}$ & Guru fokus pada isi dan pengetahuan kurikulum & Data driven \\
\hline \multirow{3}{*}{$\begin{array}{l}\text { Pembelajaran } \\
\text { Konvergen }\end{array}$} & Guru membangun ide-ide matematika peserta didik & Data driven \\
\cline { 2 - 3 } & Guru mengatasi kesalahpahaman peserta didik & Data driven \\
\cline { 2 - 3 } & Guru melibatkan peserta didik dalam pembelajaran & Data driven \\
\hline
\end{tabular}

\section{Pembelajaran Divergen}

Kategori "pembelajaran divergen" dalam penelitian ini adalah salah satu karakteristik kemampuan guru dalam melaksanakan pembelajaran matematika berbasis kurikulum 2013. Kategori tersebut termasuk kategori yang bersifat concept-driven dalam penelitian ini, karena diadaptasi dari penelitian An, Kulm, \&Wu (2004). Adapun sub-kategorinya yaitu, guru fokus pada isi dan fokus pada pengetahuan kurikulum. Berdasarkan hasil analisis isi kualitatif diperoleh yaitu, isi dan pengetahuan kurikulum, dan pemikiran peserta didik.

\section{Tema untuk isi dan pengetahuan kurikulum (GS1)}

Pada tema ini diperoleh informasi bahwa GS1 sudah dapat menyusun RPP yang sesuai dengan pedoman kurikulum 2013, tetapi belum sepenuhnya melaksanakan pembelajaran sesuai dengan tuntuan pada kurikulum 2013. Berikut kutipan hasil wawancara dengan GS1 dengan tujuan untuk mengetahui pemahaman guru tentang kurikulum 2013. 
Peneliti : Apa pendekatan pembelajaran yang disarankan untuk diterapkan dalam kurikulum 2013?

GS1 : Pendekatan Saintifik

Peneliti : Bisakah Bapak sebutkan langkah-langkah pembelajaran dengan pendekatan saintifik?

GS1 : Mengamati, menanya, emmm apalagi ya.

Peneliti : Menalar, mencoba, dan mengomunikasi. Kemudian bagaimana cara mengintegrasikan pendekatan saintifik dengan model pembelajaran yang sesuai dengan kurikulum 2013 atau misalnya saja dengan model pembelajaran PBL?

GS1 : Saya agak sedikit bingung, karena kurang memahami proses pembelajaran di kurikulum 2013.

Dengan memperhatikan tema dan kutipan wawancara, disimpulkan bahwa GS1 belum mampu melaksanakan pembelajaran kurikulum 2013 domain proses pembelajaran divergen terkait isi dan pengetahuan kurikulum.

\section{Tema untuk isi dan pengetahuan kurikulum (GS2)}

Pada tema ini diperoleh informasi bahwa RPP yang disusun oleh GS2 sudah sesuai dengan pedoman kurikulum 2013, tetapi ketika ditanya secara langsung tentang menentukan indikator pencapaian kompetensi, guru mengalami kesulitan. Pada proses pembelajaran berlangsung, guru sudah berusaha dengan baik dalam melaksanakan langkahlangkah pembelajaran berbasis kurikulum 2013. Berikut kutipan hasil wawancara dengan GS2 dengan tujuan untuk mengetahui pemahaman guru tentang kurikulum 2013.

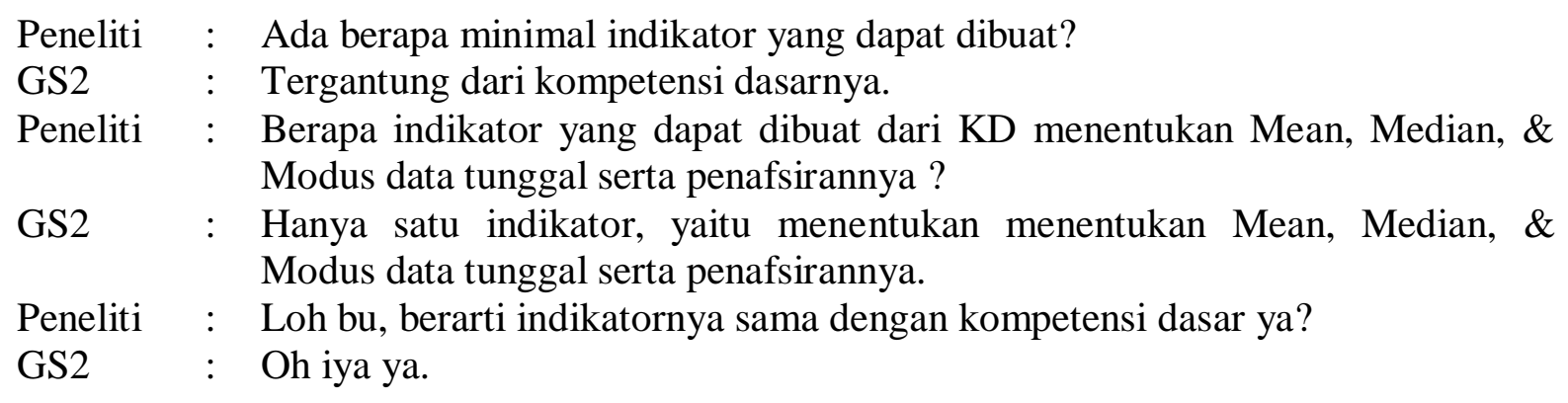

Dengan memperhatikan tema dan kutipan wawancara, disimpulkan bahwa GS2 mengalami kesulitan dalam menentukan indikator pencapaian kompetensi.

\section{Tema untuk isi dan pengetahuan kurikulum (GP1)}

Pada tema ini diperoleh informasi bahwa RPP yang disusun oleh GP1 juga sudah sesuai dengan pedoman kurikulum 2013, tetapi ketika ditanya secara langsung tentang bagaimana mengintegrasikan langkah-langkah pendekatan saintifik dengan suatu model pembelajaran tertentu, guru mengalami kesulitan. Berikut kutipan hasil wawancara dengan GP1 dengan tujuan untuk mengetahui pemahaman guru tentang kurikulum 2013.

Peneliti : Pendekatan apa yang digunakan pada pembelajaran kurikulum 2013?

GP1 : Pendekatan saintifik. 
Peneliti : Kan di dalam pembelajaran itu juga ada model pembelajaran, nah bagaimana caranya mengintegrasikan antara langkah-langkah pendekatan saintifik dengan suatu model pembelajaran tertentu, anggap saja model pembelajaran Problem Based Learning (PBL)?

GP1 : Ehhm bagaimana ya.

Dengan memperhatikan tema dan kutipan wawancara, disimpulkan bahwa GP1 mengalami kesulitan dalam mengintegrasikan langkah pendekatan saintifik dengan model pembelajaran PBL.

\section{Tema untuk isi dan pengetahuan kurikulum (GP2)}

Pada tema ini diperoleh fakta bahwa GP2 mengalami kesulitan dalam menjelaskan relevansi antara tujuan pembelajaran dan instrumen pembelajaran yang seharusnya dibuat. GP2 mengalami kesulitan ketika akan melakukan penilaian terhadap tiga aspek yang ditentukan kurikulum 2013, yaitu kognitif, afektif, dan psikomotorik. GP2 mengaku kurangnya pelatihan dalam pembuatan instrumen pembelajaran yang sesuai dengan tujuan pembelajaran kurikulum 2013. Berikut kutipan hasil wawancara dengan GP2 dengan tujuan untuk mengetahui pemahaman guru tentang kurikulum 2013.

Peneliti : Apa Anda mengalami kesulitan ketika membuat instrumen penilaian pada pembelajaran yang berbasis kurikulum 2013?

GP2 : Iya, apalagi penilaian yang dilakukan bukan hanya penilaian kognitif saja, tetapi ada afektif dan psikomotorik juga.

Peneliti : Apa solusi yang dapat dilakukan untuk mengatasi masalah tersebut?

GP2 : Ehhm bagaimana ya. Mungkin perlu dilakukan kegiatan pelatihan secara rutin terkait pembuatan instrumen penilaian pembelajaran. Kalau bisa jangan hanya sekali saja, tetapi menjadi agenda rutin.

Dengan memperhatikan tema dan kutipan wawancara, disimpulkan bahwa GP2 mengalami kesulitan dalam membuat instrumen penilaian yang sesuai dengan tujuan pembelajaran yang berbasis kurikulum 2013.

\section{Pembelajaran Konvergen}

Kategori "pembelajaran konvergen" dalam penelitian ini adalah salah satu karakteristik kemampuan guru dalam melaksanakan pembelajaran matematika berbasis kurikulum 2013. Kategori tersebut termasuk kategori yang bersifat concept-driven dalam penelitian ini, karena diadaptasi dari penelitian An, Kulm, \&Wu (2004). Adapun subkategorinya yaitu, (1) membangun ide matematika peserta didik, (2) mengatasi kesalahapahaman peserta didik, (3) melibatkan peserta didik dalam pembelajaran matematika, dan (4) meningkatkan pemikiran peserta didik secara matematis. Adapun pembahasan data tersebut adalah sebagai berikut.

Berdasarkan hasil analisis isi kualitatif, diperoleh empat tema, masing-masing untuk ide matematika peserta didik, kesalahpahaman peserta didik, keterlibatan peserta didik dalam pembelajaran, dan pemikiran peserta didik secara sistematis. 
Pada tema ini diperoleh fakta bahwa ide siswa dalam menentukan hasil dari operasi penjumlahan dan pengurangan bilangan bulat. Berikut kutipan hasil transkrip proses pembelajaran GS1.

GS1-030 : jadi sangat penting dalam mempelajari operasi ini. Andaikan kalau tidak ada bilangan bulat, bagaimana kita membedakan antara panas dan dingin, kan. Oke jadi hari ini saya mengajak kalian bagaimana melakukan operasi hitung pada bilangan bulat yang berhubungan dengan penjumlahan. Jelas? Kita ambil kasus 1, (menampilkan tayangan slide selanjutnya) kasus 1, perhatikan ya. (menulis di papan tulis) $-2-3=$ ?

SS01-031 : -5 (minus lima).

GS1-032 : darimana diperoleh minus lima ?

SS01-033 - -2-3

GS1-034 : ada lagi. (menuliskan di papan -2-(-3))

SS01-035: 5 pak.

SS01-036 : 1

GS1-037 : yang ini tadi berapa hasilnya? (menunjuk -2 - 3).

SS01-038 : -5

GS1-039 : kalau ini ? (menunjuk -2 - (-3)) berarti masih ada yang jawab 5. Jadi sekarang dua ini yang akan menjadi fokus bagaimana menyelesaikan operasi penjumlahan dan pengurangan bilangan bulat. Tapi kita sepakat dulu. Perhatikan, kita liat dulu. Kalau bilangan bulatnya positif berarti maju, kalau nol diam, kalau bilangan bulat negatif berarti mundur. Kalau berkaitan dengan operasinya, kalau dia tambah berarti terus, kalau dia kurang berarti balik arah. Nah ini (menampilkan tayangan slide $2+3$ pada garis bilangan) berapa hasilnya?

Kutipan di atas mengandung makna bahwa GS1 berhasil mengungkap salah satu kemungkinan ide matematika peserta didik dalam menentukan hasil operasi hitung bilangan bulat. Dalam hal ini GS1 mengaitkan ide matematika peserta didik dengan pengetahuan isi yang dimiliki GS1 sendiri. Oleh karena itu, GS1 dalam pembelajaran sudah memperhatikan ide matematika yang dimiliki oleh peserta didik.

\section{Tema untuk kesalahpahaman peserta didik (GS1)}

Pada tema ini GS1 menemukan kesalahpahaman peserta didik dalam menentukan hasil operasi hitung bilangan bulat. Kemudian GS1 berusaha untuk mengatasi kesalahpahaman tersebut. Berikut kutipan hasil transkrip proses pembelajaran GS1.

GS1-034 : ada lagi. (menuliskan di papan -2-(-3)).

SS01-035 : 5 pak.

SS01-036 : 1

GS1-037 : yang ini tadi berapa hasilnya? (menunjuk -2 - 3).

SS01-038 : -5

GS1-039 : kalau ini ? (menunjuk -2 - (-3)) berarti masih ada yang jawab 5. Jadi sekarang dua ini yang akan menjadi fokus bagaimana menyelesaikan operasi penjumlahan dan pengurangan bilangan bulat. Tapi kita sepakat dulu. Perhatikan, kita liat dulu. Kalau bilangan bulatnya positif berarti maju, kalau nol diam, kalau bilangan bulat negatif berarti mundur. Kalau berkaitan 
dengan operasinya, kalau dia tambah berarti terus, kalau dia kurang berarti balik arah. Nah ini (menampilkan tayangan slide $2+3$ pada garis bilangan) berapa hasilnya?

SS01-040 : 5 .

GS1-041 : kalau kita liat bilangan bulatnya, masih ingat tadi? Kalau bilangan bulatnya positif berarti dia?

SS01-042 : Maju

GS1-043 : kalau operasinya positif berarti?

SS01-044: terus.

GS1-045 : inikan bilangan bulat positif (menunjuk bilangan 2), inikan operasinya (menunjuk tanda + ), inikan juga positif (menunjuk bilangan 3) nah berarti $\mathrm{SS} 01-046: 5$ dia maju terus yahhh. Berarti jawabannya berapa?

Kutipan di atas mengandung makna bahwa GS1 berhasil mengatasi kesalahpahaman peserta didik dalam menyelesaikan soal operasi hitung bilangan bulat. Dalam hal ini GS1 mengaitkan kesalahan peserta didik dengan pengetahuan isi yang dimiliki GS1 sendiri. Oleh karena itu, GS1 dalam pembelajaran dapat mengatasi kesalahpahaman peserta didik.

\section{Tema untuk keterlibatan peserta didik dalam pembelajaran (GS1)}

Keterlibatan peserta didik dalam pembelajaran kurikulum 2013 merupakan salah satu penekanan yang harus dilaksanakan. Berdasarkan hasil transkrip video pembelajaran yang dilakukan oleh GS1 diketahui bahwa peserta didik sudah mulai dilibatkan dalam proses pembelajaran. Mulai dari awal kegiatan hingga penutup, GS1 melibatkan peserta didik dalam pembelajaran. Berikut kutipan hasil transkrip video pembelajaran GS1.

GP02-144 : oke. Sekarang perhatikan. Waktu kita tidak lama lagi. Sebelum kita lanjutkan, saya mau menanyakan, dari materi tadi itu ada yang mau ditanyakan? Siapa tau ada yang kurang paham. Ada? Kita sudah mempelajari apa semua tadi?

SS02-145 : sifat penjumlahan.

GP02-146 : bukan, sebelumnya. Yang tadi.

SS02-147 : pengertian perkalian

GP02-148 : iya, jadi ya pengertian perkalian. Jadi, perkalian tadi itu pada prinsipnya adalah?

SS02-149 : penjumlahan yang berulang.

GP02-150 : ya itu yang pertama, yang kedua? Jangan lupa apa tadi.

SS02-151 : bilangan positif kali bilangan positif hasilnya positif.

GP02-152 : iya apa lagi ?

SS02-153 : negatif kali negatif positif.

GP02-154 : ya yang ketiga apalagi?

SS02-155 : sifat-sifat perkalian.

Berdasarkan kutipan di atas GS1 mengajak peserta didik menarik kesimpulan dari hasil diskusi yang telah dilakukan sebelumnya. Oleh karena itu, GS1 telah melibatkan peserta didik dalam pembelajaran. 
Pembelajaran yang efektif adalah pembelajaran yang memberikan kesempatan kepada peserta didik untuk mengembangkan pemikiran mereka dalam menemukan suatu konsep tertentu (Kulm, Caprapro, Capraro, Burghardt, \& Ford, 2001). GS1 sudah mencoba untuk meningkatkan pemikiran peserta didik secara sistematis.

\begin{tabular}{|c|c|c|}
\hline GS1-093 & & apa kemarin itu komutaif? \\
\hline SS02-094 & • & Pertukaran \\
\hline GS1-095 & & jadi coba 1 orang dari kelompokk bilangan genap. Jelaskan. \\
\hline SS02-096 & & $a \times b=b \times a$ \\
\hline GS1-097 & & contohnya? Ambil sembarang bilangan. \\
\hline SS02-098 & & $4 \times 5=5 \times 4=20$ \\
\hline GS1-099 & & $\begin{array}{l}\text { yang kedua? asosiatif coba. Untuk setiap bilangan a, b dan c berlaku apa? } \\
\text { asosiatif atau distributif begitu? }\end{array}$ \\
\hline SS02-100 & & asosiatif pengelompokan. \\
\hline GS1-101 & & $\begin{array}{l}\text { ya jadi kurungnya yang berpindah ya. Nah kalau distributif? Itu ada } \\
\text { berapa? }\end{array}$ \\
\hline SS02-102 & & 2 \\
\hline GS1-103 & & distributif perkalian tehadap penjumlahan, \\
\hline SS02-104 & & dan terhadap pengurangan \\
\hline GS1-105 & & $\begin{array}{l}\text { nah sekarang tugas kelompok silahkan kalian kerja dulu. Tabel 1.2. } \\
\text { Perhatikan kelompok-kelompoknya saya bagikan tugasnya (memberikan } \\
\text { tugas pada masing-masing kelompok). Jadi per kelompok ya kalian } \\
\text { kerjanya, sudah saya bagi tadi masing-masing tugas kelompoknya. } \\
\text { Silahkan dikerja \{berkeliling mengamati siswa sambil membawa lembar } \\
\text { penilaian). }\end{array}$ \\
\hline
\end{tabular}

Kutipan di atas mengandung makna bahwa GS1 membimbing peserta didik untuk menemukan sifat-sifat operasi hitung perkalian pada bilangan bulat dengan cara diskusi kelompok. Jadi dapat disimpulkan bahwa GS1 dalam pembelajaran berusaha meningkatkan pemikiran peserta didik secara sistematis.

Tema untuk ide matematika peserta didik (GS2)

Pada tema ini akan dilihat ide peserta didik dalam membaca diagram yang diberikan oleh guru. GS2 membagi peserta didik ke dalam beberapa kelompok untuk menyelesaikan suatu masalah. Berikut kutipan hasil transkrip proses pembelajaran GS2.

GS2-117 : oke waktunya habis, silahkan dikumpul pekerjaannya dan perwakilan kelompok ibu tunjuk secara acak maju ke depan. Saya minta satu orang baca soal nomor 1. Kelompok ini ya, kelompok E (menunjuk kelompok E\}. Silahkan baca hasil diskusi kelompoknya. Yang lain silahkan simak dan cocokkan jawaban kalian dengan kelompok ini.

SS01-118 : (membaca hasil diskusi kelompoknya).

GS2-119 : yang lain didengar ya, dicocokkan dengan jawabannya kamu. Dimana letak bedanya.

SS01-120 : (kembali ke tempat duduknya).

GS2-121 : oke yang lain. Sama atau tidak jawabannya? (bertanya dengan kelompok lain).

SS01-122 : Beda kami bu. (kelompok A) 
GS2-123 : iya kelompok A. Mana yang tidak sama jawabannya. Yang lain dengar yaa (memerintahkan siswa lain untuk memperhatikan). Kita dengar apa jawabannya. Baca Lina.

SS01-124 : (maju ke depan membacakan hasil diskusinya).

GS21-125 : coba didengar. Yang lain, kelompok C dan D, coba dengar dan bandingkan sama atau tidak dengan jawabanmu. Oke silahkan dibaca, tidak usah soalnya dibaca lagi ya karena semuanya sudah ada soal nya, jadi langsung jawabannya saja.

SS01-126 : (membacakan hasil diskusi kelompoknya, yaitu kelompok A).

(Bel istirahat berbunyi).

GS21-127 : kasi selesai dulu temanmu membaca ya baru istirahat.

SS01-128 : sudah bu. (siswa selesai membacakan jawabannya).

GS21-129 : soal nomor 1, sama jawabannya dengan kelompok A?

SS01-130 : (sebagian berdiskusi, sebagian berkemas istirahat).

SS01-131 : Iya Bu, sama.

GS21-132 : iyaaa, kalau dikelompok ini (kelompok D) cara membaca diagramnya hanya beda di awal kalimatnya saja yaaa, hampir sama dengan kelompok A. Kalau bagian a di kelompok D, mereka menyebutkan dulu itu jenis diagram garis. Kemudian cara membacanya, sedangkan kelompok A langsung cara membacanya. (bersama-sama siswa mendiskusikan hasil pekerjaan kelompok siswa). Saya kira itu sudah sama semua, hanya bagian a saja yang berbeda. Oke. Lanjut ke nomor 2

Kutipan di atas mengandung makna bahwa GS2 berhasil mengungkap salah satu kemungkinan ide matematika peserta didik dalam membaca diagram. Dalam hal ini GS2 mengaitkan ide matematika peserta didik dengan pengetahuan isi yang dimiliki GS2 sendiri. Oleh karena itu, GS2 dalam pembelajaran sudah memperhatikan ide matematika yang dimiliki oleh peserta didik.

\section{Tema untuk kesalahpahaman peserta didik (GS2)}

Pada tema ini GS2 menemukan kesalahpahaman peserta didik dalam menentukan hasil operasi hitung bilangan bulat. Kemudian GS2 berusaha untuk mengatasi kesalahapahaman tersebut. Berikut kutipan hasil transkrip proses pembelajaran GS2.

GS2-138 : median, bagaimana kalo dia ganjil. Kalau datanya ganjil, bagaimana mediannya?

SS02-139 : yah yang di tengahnya bu (sambil tersenyum).

GS2-140 : oke, yah coba Alif. Sama nda dengan jawabanmu?

SS02-141 : beda bu (berdiri). Median adalah data yang diurutkan dari yang terkecil sampai yang terbesar dan dibagi di tengah-tengah data tersebut, jikalau data tersebut genap maka harus ditambah kemudian dibagi dua. Jikalau data itu ganjil tinggal ditentukan ditengah-tengahnya saja.

GS2-142 : iyaaa, coba ulang. Kalau genap tadi bagaimana?

SS02-143 : jikalau data tersebut genap maka harus ditambah kemudian...

GS2-144 : ditambah dengan apa?

SS02-145 : ditambah dengan bilangan yang sama

GS2-146 : (menggeleng) ehmmm.

SS02-147 : eh data yang sama. 
GS2-148 : bagaimana itu data yang sama? saya tanya yang lain, tadi ditambah ndak datanya ?

SS02-149 : disatukan

GS2-150 : ohh jadi itu maksudnya, diambil nilai yang berada ditengah, bukan ditambah ya. Nah kalau ganjil. Jadi kalau dia bilangan ganjil ditambah 1 baru dibagi 2 , nah itulah yang berdiri ditengah. Tadi 9 , jumlah datanya kan 9, berarti ganjil, ditambah 1, jadi 10, nah 10:2, berarti data yang urutan ke?

SS02-151 : Lima.

Kutipan di atas mengandung makna bahwa GS2 berhasil mengatasi kesalahpahaman peserta didik dalam menentukan median untuk data genap. Dalam hal ini GS2 mengaitkan kesalahan peserta didik dengan pengetahuan isi yang dimiliki GS2 sendiri. Oleh karena itu, GS2 dalam pembelajaran dapat mengatasi kesalahpahaman peserta didik.

\section{Tema untuk keterlibatan peserta didik dalam pembelajaran (GS2)}

Keterlibatan peserta didik dalam pembelajaran kurikulum 2013 merupakan salah satu penekanan yang harus dilaksanakan. Berdasarkan hasil transkrip video pembelajaran yang dilakukan oleh GS2 diketahui bahwa peserta didik sudah mulai dilibatkan dalam proses pembelajaran. Mulai dari awal kegiatan hingga penutup, GS2 melibatkan peserta didik dalam pembelajaran. Berikut kutipan hasil transkrip video pembelajaran GS2.

: $\quad$ kumpulan informasi yang penting yang diperoleh didalam suatu penelitan.

GS2-041 Iya oke. Coba ya. Sekarang kita masih lanjutkan materi kelas 8, yang lalu kita sudah memperoleh data, kita menyajikan data. Nah menyajikan data itu ada berapa cara?

SS01-042 : 2 bu.

SS01-043 : yaa apa saja ?

SS01-044 : diagram batang.

GS2-045 : ya ada diagram batang.

SS01-046 : Tabel (bersama-sama dengan guru).

GS2-047 : ada yang dikumpulkan dengan disajikan dalam bentuk diagram batang, dan dalam bentuk tabel. (bersama-sama dengan siswa) sekarang kita akan lanjutkan masalah tadi. Masih ingat ini? (menunjukkan tayangan slide macam-macam bentuk penyajian data])kalau ini disebut apa?

SS01-048 : Masiihhh.

GS2-049 : ayo ini bentuk apa?

SS01-050 : ituuu, diagram.

GS2-051 : iya diagram. Kalau gambar yang ujung sana? Disebut diagram apa? (menunjukkan diagram garis).

SS01-052 : Gari.s

GS2-053 : diagram garis. Nah kalau yang ini?(menunjukkan gambar diagram batang).

SS01-054: batang.

GS2-055 : kalau yang ini? (menunjukkan gambar diagram batang).

SS01-056 : diagram batang juga

GS2-057 : oke nah kalau yang ini? (menunjukkan gambar diagram lingkaran).

SS01-058 : diagram lingkaraaan. 
GS2-059 : iyaa betul diagram lingkaran. Yaa jadi di sini adalah contoh-contoh penyajian data yang sudah dikumpulkan dan disajikan dalam bentuk diagram. Ada yang namanya diagram garis, (bersaman-sama dengan siswa, ada data tentang jumlah siswa yang diterima di SMA dari tahun 1980-1986, kemudian ada juga tentang data nomor sepatu. Selain dalam bentuk diagram, Nah kalau yang ini? (menunjukkan contoh penyajian data dalam bentuk tabel).

SS01-060 : Tabel ibu.

Berdasarkan kutipan di atas GS2 mengajak peserta didik membahas materi tentang penyajian data. Jadi GS2 telah melibatkan peserta didik dalam pembelajaran.

Tema untuk pemikiran peserta didik secara sistematis (GS2)

Pembelajaran yang efektif adalah pembelajaran yang memberikan kesempatan kepada peserta didik untuk mengembangkan pemikiran mereka dalam menemukan suatu konsep tertentu (Kulm, Caprapro, Capraro, Burghardt, \& Ford, 2001). GS2 sudah mencoba untuk meningkatkan pemikiran peserta didik secara sistematis. Berikut kutipan hasil transkrip video pembelajaran GS2.

GS2-113 : ya sekarang silahkan catat hasil diskusi kita. Nah sekarang rata-rata atau yang disebut dengan mean. Bagaimana caranya memperoleh ratarata?

SS02-114 : Ehmmm

GS2-115

Semuanya (menunjuk semua anggota kelompok B) kita jumlahkan. jumlahkan semua anggotanya disini, berapa?

SS02-116 : ada 12 orang

GS2-117 : ya coba tulis berapa jumlahnya. Kemudian yang di sini juga (kelompok A). Rata-ratanya semua data yang ada dijumlahkan baru bagi dengan banyaknya data.

SS02-118 : (kerja sama dengan kelompoknya mengerjakan tugas yang diperintah guru).

GS2-119 : nah kalau yang sudah, perwakilan kelompoknya tulis di papan. Kelompok A dulu.

SS02-120 : (maju ke depan dan menuliskan jawabannya).

GS2-121 : : yang lain jangan ribut yaa.

SS02-122 : (masing-masing kelompok menuliskan jawabannya).

GS2-123 : nah sekarang perhatikan. Untuk kelompok A meannya dicari dengan menjumlahkan semua datanya. Selanjutnya, setelah dijumlah baru dibagi. Mereka ada 9 orang, berarti dibagi 9 dapat rata-ratanya 38. Nah jadi rata-rata bisa menyimpulkan bahwa rata-rata sepatu untuk kelompok A disini adalah 38. Nah sekarang coba kelompok yang genap. Berapa?

SS02-124 : 481 bagi..

SS02-125 : Bagi 12

GS2-126 : berapa? 481 (sambil menuliskan jawabannya di papan] bagi 12 ya kan ada 12 orang. Bagi 12 dapat berapa?

SS02-127 : 40 koma ibu.

GS2-128 : (sambil menghitung di papan bersama siswa) berapa dapatnya? 
SS02-129 : 40,08

GS2-130 : nah jadi itu cara memperoleh mean. Ada pertanyaan? Ada?

Kutipan di atas mengandung makna bahwa GS2 membimbing peserta didik untuk menentukan nilai mean dari satu data secara sistematis. Jadi dapat disimpulkan bahwa GS2 dalam pembelajaran berusaha meningkatkan pemikiran peserta didik secara sistematis.

\section{Tema untuk ide matematika peserta didik (GP1)}

Pada tema ini akan dilihat ide peserta didik dalam menentukan hasil perhitungan bilangan berpangkat berdasarkan sifat-sifatnya. Berikut kutipan hasil transkrip proses pembelajaran GP1.

SS02-207 : Jadi misalnya 1 per 3 pangkat $4\left(\frac{1}{3^{4}}\right)$ sama dengan 1 bagi 3 (diam sejenak karena ragu dan bertanya ke guru).

GP1-208 : Silahkan jawabanmu kan

SS02-209 : Sama dengan 3 pangkat 0 bagi 3 pangkat $4\left(3^{0}: 3^{4}\right)$. Nah sifat yang ke berapa, yang ke empat (berpikir).

SS02-210 : Iya.

SS02-211 : Sifat yang ke empat itu kan kalau misalnya dibagi itu pangkatnya dikurang, sama dengan 0 dikurang 3 pangkat 0 kurang 4 (siswa tersebut salah bicara awalnya) hasilnya 3 pangkat min $4\left(3^{-4}\right)$.

GP1-212 : Jadi kesimpulannya?

SS02-213 : Jadi kesimpulannya itu kalau misalnya ini (melingkari tulisan di papan tulis) sama saja dengan ini.

GP1-214 : Apa itu?

SS02-215 : Ini sifatanya, kalau a pangkatnya minus itu sama saja dengan 1 per a pangkat $\mathrm{n}\left(\frac{1}{a^{n}}\right)$.

SS02-216 : (bertepuk tangan).

GB02-217 : Oke ada yang mau ditanya?

SS02-218 : (angkat tangan).

GB02-219 : Oke silahkan.

SS02-220 : (bertanya tapi suaranya tidak kedengaran intinya yang dia tanyakan adalah kenapa 3 pangkat nol berupa jadi 3 pangkat 4).

Kutipan di atas mengandung makna bahwa GP1 berhasil mengungkap salah satu kemungkinan ide matematika peserta didik tentang aturan atau sifat perpangkatan. Dalam hal ini GP1 mengaitkan ide matematika peserta didik dengan pengetahuan isi yang dimiliki GP1 sendiri. Oleh karena itu, GP1 dalam pembelajaran sudah memperhatikan ide matematika yang dimiliki oleh peserta didik.

\section{Tema untuk kesalahpahaman peserta didik (GP1)}

Pada tema ini GP1 menemukan kesalahpahaman peserta didik dalam menentukan hasil operasi hitung bilangan berpangkat. Kemudian GP1 berusaha untuk mengatasi kesalahapahaman tersebut. Berikut kutipan hasil transkrip proses pembelajaran GP1.

GP1-229 : Kalau begitu Mem yang bertanya. Oke Fatan berdiri. Kenapa di 1 bagi 3 pangkat $4\left(1: 3^{4}\right)$ yang ini (menunjuk papan tulis) tiba-tiba di sini 


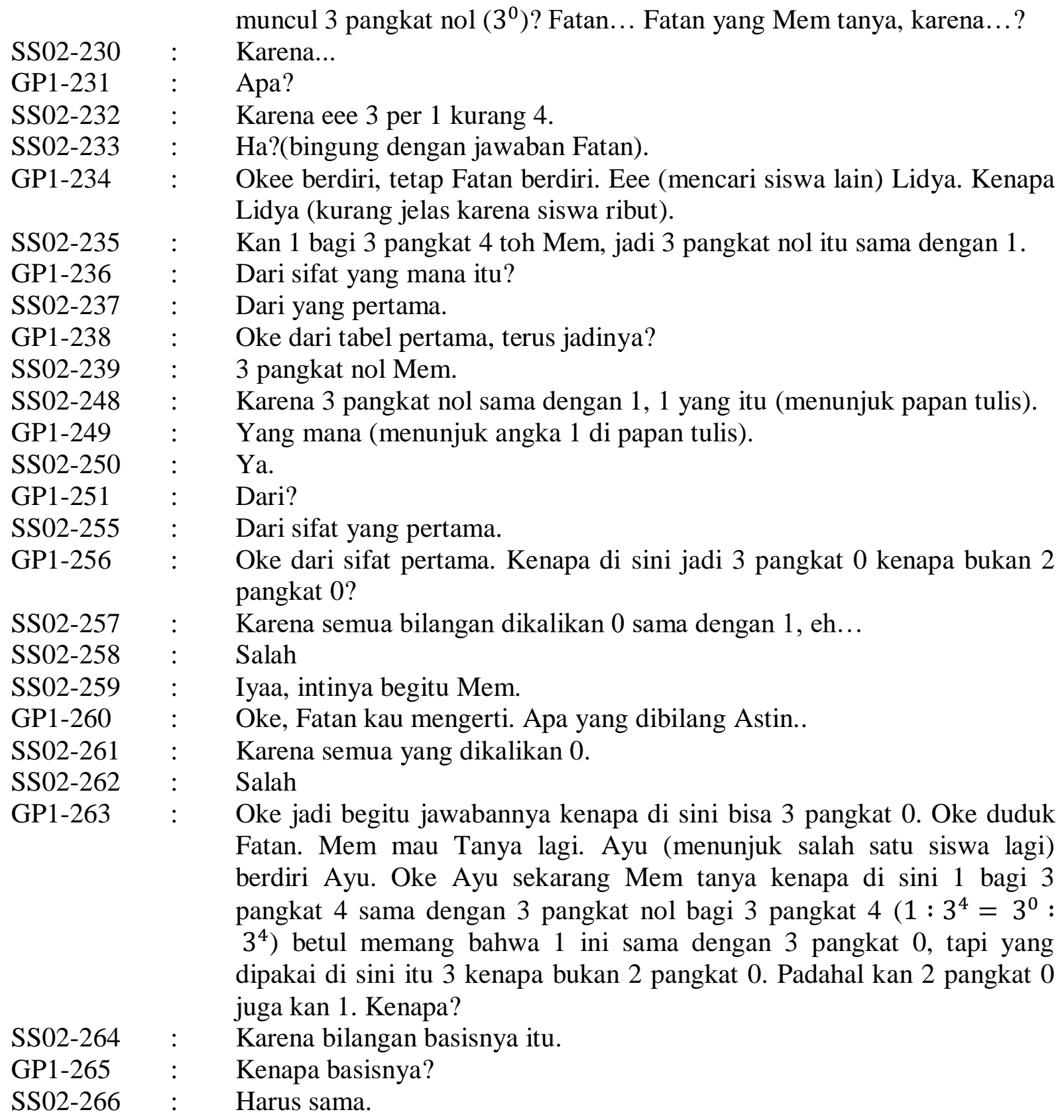

Kutipan di atas mengandung makna bahwa GP1 berhasil mengatasi kesalahpahaman peserta didik dalam menentukan hasil perhitungan bilangan berpangkat. Dalam hal ini GP1 mengaitkan kesalahan peserta didik dengan pengetahuan isi yang dimiliki GP1 sendiri. Oleh karena itu GP1, dalam pembelajaran dapat mengatasi kesalahpahaman peserta didik.

\section{Tema untuk keterlibatan peserta didik dalam pembelajaran (GP1)}

Keterlibatan peserta didik dalam pembelajaran kurikulum 2013 merupakan salah satu penekanan yang harus dilaksanakan. Berdasarkan hasil transkrip video pembelajaran yang dilakukan oleh GP1 diketahui bahwa peserta didik sudah mulai dilibatkan dalam proses pembelajaran. Mulai dari awal kegiatan hingga penutup, GP1 melibatkan peserta didik dalam pembelajaran. Berikut kutipan hasil transkrip video pembelajaran GP1. 
SS01-078 : assalamualaikum warahmatullahi wabarakatuh, jadi kami akan menjelaskan tabel 2, kita lihat contoh di tabel 1 pemangkatan pada perpangkatannya $\left(6^{2}\right)^{2}$ jadi $6^{2}$ dalam bentuk operasi perkaliannya didahulukan $\left(6^{2}\right)$ sebanyak dua kali kemudian kita jabarkan lagi 6 x 6 x 6 x 6 karena di sini kita tidak perlu lagi menjabarkan maka pangkatnya bisa dikali yaitu pangkatnya 2 maka 2 x 2 dan kemudian basisnya sama jadi pangkatnya kita kalikan jadi nilai perpangkatannya $6^{4}=6^{2 x 2}$, sekian dari kami.

GP1-079 : ada yang berbeda jawabannya ?

SS01-080 : Tidak

GP1-081 : berikan tepuk tangan untuk kelompok 2, kita lanjut ke tabel 3, kelompok 3 silahkan.

SS01-082 : assalamualaikum warahmatullahi wabarakatuh, kami akan menjelaskan tabel 3, kita lihat contoh nomor 1 pemangkatan dalam perkalian bilangan $(2 \times 3)^{2}$ operasi perkaliannya $2 \times 3 \times 2 \times 3=2 \times 2 \times 3 \times 3$ dalam perpangkatannya itu $2^{2} \times 3^{2}$ jadi kesimpulannya itu $(a \times b)^{n}=a^{n} \times b^{n}$.

GP1-082 : dari kelompok 4 bagaimana ? jawabannya sama ?

SS01-083 : menurut kami ibu cara yang lebih mudahnya pangkatnya kita kali masuk, karena pangkatnya sama.

GP1-084 : ada jawaban yang berbeda?

SS01-085 : Tidak

GP1-086 : tepuk tangan untuk kelompok 3 dan 4, kita lanjut ke kelompok 4.

SS01-087 : kami akan menjelaskan sifat perpangkatan dari tabel 4 menurut kami jika bilangan dasarnya sama maka pangkat yang di bawah bisa dipindah ke atas apabila negative (-) menjadi positif (+) begitupun sebaliknya.

GP1-088 : jadi dari kelompok bagaimana bentuk umumnya?

SS01-089 : jadi bentuk umumnya $\frac{a^{m}}{a^{n}}=a^{m-n}$

Berdasarkan kutipan di atas GP1 mengajak peserta didik membahas materi tentang aturan perkalian bilangan berpangkat. Jadi GP1 telah melibatkan peserta didik dalam pembelajaran.

\section{Tema untuk pemikiran peserta didik secara sistematis (GP1)}

Pembelajaran yang efektif adalah pembelajaran yang memberikan kesempatan kepada peserta didik untuk mengembangkan pemikiran mereka dalam menemukan suatu konsep tertentu (Kulm, Caprapro, Capraro, Burghardt, \& Ford, 2001). GP1 sudah mencoba untuk meningkatkan pemikiran peserta didik secara sistematis. Berikut kutipan hasil transkrip video pembelajaran GP1.

GP12-281 : Oke sekarang semua sudah mengerti kan, jadi ada dua sifat yang kalian dapat. Apa sifat pertama?

SS02-282 : a pangkat 0 sama dengan $1\left(a^{0}=1\right)$.

GP1-283 : Maksudnya apa?

SS02-284 : Semua bilangan yang berpangkat nol hasilnya 1.

GP1-285 : Oke sifat kedua apa?

SS02-286 : a pangkat min $\mathrm{n}$ sama dengan 1 per a pangkan $\mathrm{n}\left(a^{-n}=\frac{1}{a^{n}}\right)$.

GP1-287 : Maksudnya apa? 


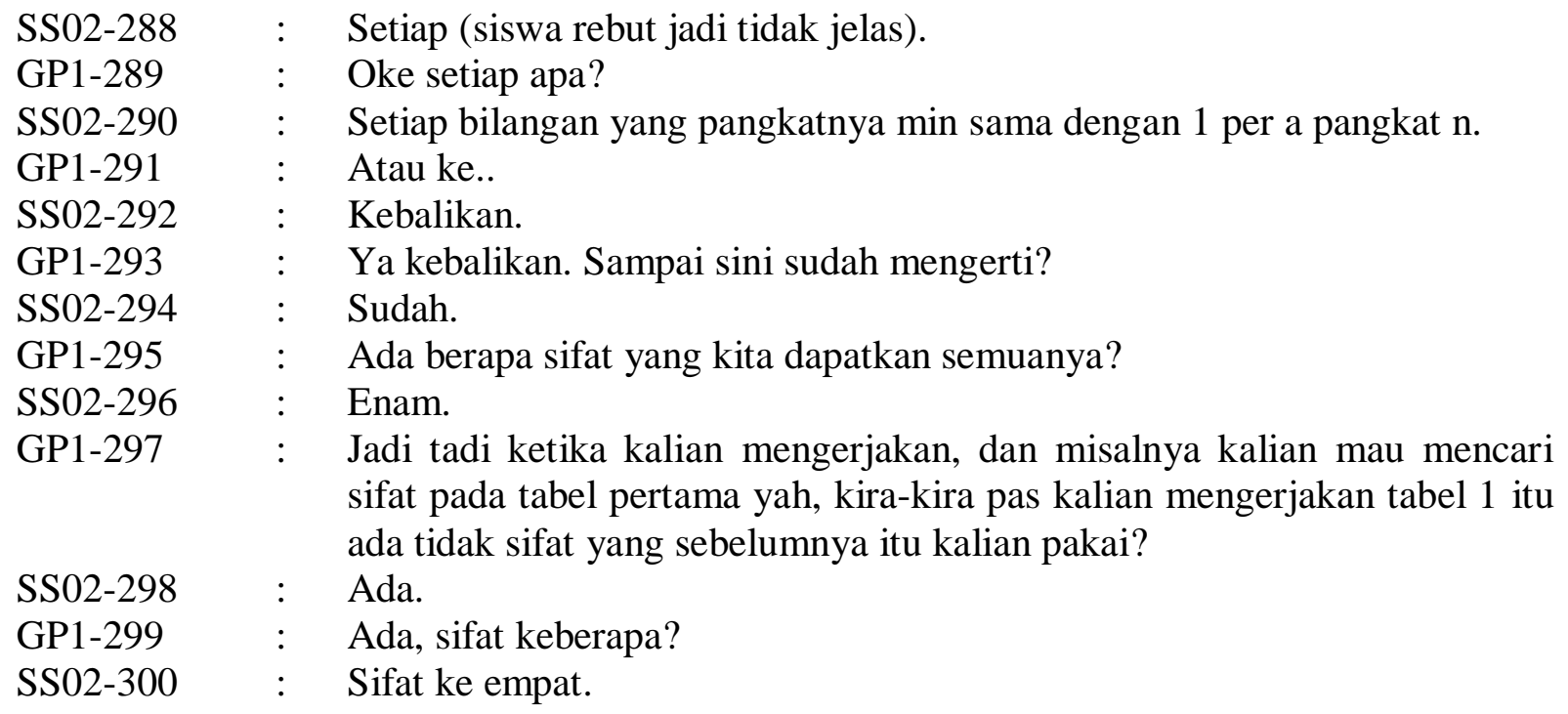

Kutipan di atas mengandung makna bahwa GP1 membimbing peserta didik untuk menentukan hasil perhitungan bilangan berpangkat berdasarkan sifat-sifatnya. Jadi dapat disimpulkan bahwa GP1 dalam pembelajaran berusaha meningkatkan pemikiran peserta didik secara sistematis.

Tema untuk ide matematika peserta didik (GP2)

Pembelajaran yang dilakukan oleh GP2 masih berpusat pada guru, bukan pada peserta didik. Peserta didik lebih banyak ribut daripada memperhatikan dan mengikuti kegiatan pembelajaran, sehingga ide matematika peserta didik kurang terlihat. GP2 membagi peserta didik ke dalam beberapa kelompok untuk menyelesaikan suatu masalah, tetapi hal tersebut berakibat peserta didik ribut. Berikut kutipan hasil transkrip proses pembelajaran GP2.

SS01-107 : Ya baik, kelompok kami. Kami mendapatkan jawaban eee dalam 3 kelompok (menjelaskan jawabannya) dari kelompok 1 perempuannya jumlahnya 3 laki-lakinya jumlahnya 2 .

SS01-108 : 3 laki-lakinya.

SS01-109 : (siswa lain ribut sehingga tidak jelas apa yang dikatakan temannya).

GP2-110 : Kenapa sampai kau bilang ini hasil observasi dari data yang ini. Ini kan data semua yang kamu dapat. Kenapa bisa observasi?

SS01-111 : Kenapa observasi? Karena kita...

GP2-112 : Coba perhatikan.

SS01-113 : Karena kita mengamati (sambil ketawa).

GP2-114 : Oke maksudnya begini, dia ambil observasi karena hasilnya dari mengamati (menjelaskan maksud jawaban dari kelompok 3).

Kutipan di atas mengandung makna bahwa GP2 berhasil mengungkap salah satu kemungkinan ide matematika peserta didik. Dalam hal ini GP2 mengaitkan ide matematika peserta didik dengan pengetahuan isi yang dimiliki GP2 sendiri. Oleh karena itu GP2 dalam pembelajaran sudah memperhatikan ide matematika yang dimiliki oleh peserta didik.

Tema untuk kesalahpahaman peserta didik (GP2) 
Pada tema ini GP2 menemukan kesalahpahaman peserta didik dalam menuliskan urutan bilangan. Kemudian GP2 berusaha untuk mengatasi kesalahpahaman tersebut. Berikut kutipan hasil transkrip proses pembelajaran GP2.

GP2-044 : Coba perhatikan (melihat jawaban siswa). Nah di sini kalau kalian mau mengurutkan, ini kan ada 65. Ada berapa? 65 cuma 1, 73 ada 1 yah, terus 75 ?

SS01-045 : Ada 3

GP2-046 : Ada 3 yah, seharusnya kalian tulis di sini 75 ada (menulis 75 sebanyak 3 kali) terus 78 ada 2 yah (menulis 78 ) terus.. ada berapa 79 ?

SS01-047 : Satu.

GP2-048 : $\quad$ Terus 80, terus 82 ada 2 yah, terus 83 .

SS01-049 : Satu

GP2-050 : 84?

SS01-051 : Satu juga.

GP2-052 : 85?

SS01-053 : Dua

GP2-054 : Dua yah (menulis 85), terus 86? 1 yah. 88, 90, 9598 ada 1. Nah keseluruhan nilainya berapa? 1, 2, 3, ..., 30. Sama begitu juga bagian B ini. Terus dari nomor 1 ini ada yang mau bertanya? Ada yang belum dipahami? Gampang yah.

SS01-055 : Gampang.

Kutipan di atas mengandung makna bahwa GP2 berhasil mengatasi kesalahpahaman peserta didik dalam menuliskan urutan bilangan. Dalam hal ini GP2 mengaitkan kesalahan peserta didik dengan pengetahuan isi yang dimiliki GP2 sendiri. Oleh karena itu, GP1 dalam pembelajaran dapat mengatasi kesalahpahaman peserta didik.

\section{Tema untuk keterlibatan peserta didik dalam pembelajaran (GP2)}

Keterlibatan peserta didik dalam pembelajaran kurikulum 2013 merupakan salah satu penekanan yang harus dilaksanakan. Berdasarkan hasil transkrip video pembelajaran yang dilakukan oleh GP2 diketahui bahwa peserta didik tidak terlibat secara aktif. Pembelajaran masih berpusat pada guru dan sebagian besar peserta didik sibuk dengan kegiatannya masing-masing. Berikut kutipan hasil transkrip video pembelajaran GP2.

GP2-094 : (berjalan melihat setiap kelompok dan menjelaskan apa yang ditanyakan). SS01-095 : (siswa masih ribut).

GP2-096 : (mengamati setiap kelompok dan menjelaskan di depan tetapi tidak jelas apa yang dikatakan karena siswa ribut sekali).

(masih berjalan-jalan ke setiap kelompok dan menjelaskan apa yang tidak diketahui kelompok).

SS01-097 :

GP2-098 : Coba perhatian yah. Siapa yang mau maju? Kelompok mana yang mau maju? (sambil mengangkat tangannya).

SS01-099 : (siswa masih ribut).

GP2-100 : Coba perhatian (mengetuk-ngetuk papan tulis] siapa yang mau maju? (menghampiri kelompok 3). Ayo... saya tunjuk ini saja (menunjuk 
seorang siswa di kelompok 3).

SS01-101 : (maju mengerjakan hasil pekerjaannya di papan tulis).

GP2-102 : Ayo.. kelompok 2 bagaimana? (menghampiri kelompok 2).

SS01-103 : (banyak siswa yang keluar-masuk kelas).

Berdasarkan kutipan di atas, peserta didik tidak terlibat secara aktif dalam proses pembelajaran. Jadi GP2 belum melibatkan peserta didik dalam pembelajaran.

\section{Tema untuk pemikiran peserta didik secara sistematis (GP2)}

Pembelajaran yang efektif adalah pembelajaran yang memberikan kesempatan kepada peserta didik untuk mengembangkan pemikiran mereka dalam menemukan suatu konsep tertentu (Kulm, Caprapro, Capraro, Burghardt, \& Ford, 2001). GP2 belum fokus pada peningkatan pemikiran peserta didik secara sistematis. Hal ini disebabkan proses pembelajaran yang kurang kondusif. Banyak peserta didik yang ribut dan keluar masuk kelas.

\section{KESIMPULAN}

Karakter kemampuan guru yang lebih menuju pada pembelajaran divergen adalah pembelajaran yang fokus pada isi serta kurikulumnya dan mengabaikan pemikiran peserta didik. Pada penelitian ini diperoleh hasil bahwa pada pelaksanaan pembelajaran, guru tidak berpedoman pada RPP yang telah mereka buat. RPP yang disusun oleh guru sudah sesuai dengan pedoman kurikulum 2013, tetapi ketika ditanya secara langsung tentang pemahaman terhadap kurikulum 2013, guru mengalami kesulitan. Oleh karena itu, karakteristik kemampuan guru dalam proses pembelajaran tidak menuju kepada pembelajaran divergen.

Karakter kemampuan guru yang lebih menuju pada pembelajaran konvergen adalah pembelajaran yang fokus untuk membangun ide matematika peserta didik, mengatasi kesalahapahaman peserta didik, melibatkan peserta didik dalam pembelajaran matematika, dan meningkatkan pemikiran peserta didik secara matematis.

Berdasarkan hasil analisis diperoleh bahwa GS1, GS2, GP1, dan GP2 sudah berhasil mengungkap salah satu kemungkinan ide matematika peserta didik dalam pembelajaran, hanya saja untuk GP2 tidak terlihat jelas karena pembelajarannya kurang kondusif. Selanjutnya untuk hal mengatasi kesalahpahaman peserta didik, GS1, GS2, GP1, dan GP2 berhasil mengatasi kesalahpahaman peserta didik dalam menyelesaikan masalah yang ada dalam proses pembelajaran.

Keterlibatan peserta didik juga menjadi perhatian pada pembelajaran kovergen. Pada proses pembelajaran, GS1, GS2, dan GP1 telah mengajak peserta didik membahas materi pembelajaran secara bersama-sama. Akan tetapi ada pembelajaran yang dilaksanakan oleh GP2, peserta didik tidak terlibat secara aktif dalam proses pembelajaran.

Pembelajaran yang efektif adalah pembelajaran yang memberikan kesempatan kepada peserta didik untuk mengembangkan pemikiran mereka dalam menemukan suatu konsep tertentu. GS1, GS2, dan GP1 telah membimbing peserta didik untuk menemukan konsep-konsep dalam matematika dengan cara diskusi kelompok, sedangkan GP2 belum fokus pada peningkatan pemikiran peserta didik secara sistematis. Hal ini disebabkan proses pembelajaran yang kurang kondusif. Banyak peserta didik yang ribut dan keluar masuk kelas. Jadi karakteristik kemampuan guru dalam proses pembelajaran menuju kepada pembelajaran konvergen. 
40 AKSIOMA, Volume 9 Nomor 1, Maret 2020

\section{REFERENCES}

Aryani, M. F. (2014). Studi Kasuk Penerapan Pendekatan Saintifik pada Guru-Guru di SMA N 1 Bawang (Studi pada Tahun Ajaran 2013/2014). Economic Education Analysis Journal. ISSN: 2252-6544, Volume 3. No. 3. Hal. 558-563.

Jihad, A. \& Haris, A. (2008). Evaluasi Pembelajaran. Jakarta: Multi Press.

Atkin, M. J. \& Paul, B. (2003) Inside science education reform: A history of curricular and policy change. New York: Teachers College Press.

Budiyanto, M. A. K., Waluyo, L., \& Mokhtar, A. (2016). Implementasi Pendekatan Saintifik dalam Pembelajaran di Pendidikan Dasar di Malang. Proceeding Biology Education Conference. ISSN: 2528-5742, Volume. 13, Hal. 46-51. Malang: BEC.

Capay, M. \& Magdin, M. (2013). Tasks for teaching scientific approach using the black box method. Academic Conferences and Publishing International Limited. Diambil pada tanggal 20 Juli 2018, dari https://www.researchgate.net.

Creswell, J.W. (2010). Research Design Qualitative, Quantitative, and Mixed Methods Approaches. Third Edition. California: Sage Publication

Darnius, S. (2016). Identifikasi Kesulitan Guru dalam Mengimplementasikan Kurikulum 2013 dengan Pendekatan Saintifik di Kelas Tinggi Gugus Mangga Kecamatan Jaya Baru Banda Aceh. Jurnal Pesona Dasar. ISSN: 2337-9227, Volume. 2. No. 4. Hal. 40-48.

Erny, Haji, S., \& Widada, W. (2017). Pengaruh Pendekatan Saintifik pada Pembelajaran Matematika terhadap Kemampuan Pemecahan Masalah dan Kemampuan Berpikir Tingkat Tinggi Peserta didik Kelas X IPA SMA Negeri 1 Kepahiang. Jurnal Pendidikan Matematika Raflesia. Volume. 2, No. 1. Hal. 1-22.

Hosnan, M. (2014). Pendekatan saintifik dan kontekstual dalam pembelajaran abad 21 kunci sukses implementasi kurikulum 2013. Bogor: Ghalia Indonesia.

Kusmaharti, D. \& Prayitno, L. L. (2017). Analisis Kesulitan Guru SD di Kabupaten Sumenep dalam Mengajarkan Tema pada Kurikulum 2013. INOVASI. Volume. XIX. No. 1. Hal. 24-32.

Mahmudi, A. (2015). Pendekatan Saintifik dalam Pembelajaran Matematika. Seminar Nasional Matematika dan Pendidikan Matematika UNY 2015. ISBN. 978-602-734030-5. Hal. 561-566.

Mendikbud. (2013). Peraturan Menteri Pendidikan dan Kebudayaan Nomor 81A Tahun 2013, tentang Implementasi Kurikulum Pedoman Umum Pembelajaran.

Michael, R. S. (2002). Strategies for educational inquiry: inquiry and scientific methods. Fall 2002-Y520: 5982, page 3

Muhibbin Syah. (2006). Psikologi belajar. Jakarta: Raja Grafindo Persada.

Muliatina. (2016). Kendala Guru dalam Menerapkan Pendekatan Saintifik pada Kurikulum 2013 di SDN Teupin Pukat Meureudu Pidie Jaya. Jurnal Ilmiah Mahasiswa Prodi PGSD FKIP Unsiyah. Volume 1. No. 1, Hal. 129-136. 
Mulyadi. (2010). Diagnosis kesulitan belajar. Yogyakarta: Nuha Litera.

Musfiqon, H. M., \& Nurdyansyah. (2015). Pendekatan pembelajaran saintifik. Sidoarjo: Nizamia Learning Center.

Ningsih, H. S., Koryati, D., \& Deskoni. (2016). Analisis Kesulitan Guru dalam Menerapkan Pembelajaran Saintifik pada Mata Pelajaran IPS di SMP Negeri Kota Palembang. Jurnal Profit. Volume 3. No. 2. Hal. 130-138.

Nurdyansyah \& Fahyuni, E. F. (2016). Inovasi model pembelajaran sesuai kurikulum 2013. Sidoarjo: Nizamia Learning Center.

Santrock, J. (2011). Educational psychology (5 $\left.5^{\text {th }} e d\right)$. New York: Mc. Graw Hill.

Shuhua An, Kulm, G., \& Wu, Z. (2004). The pedagogical content knowledge of middle school, mathematics teachers in China and The U.S. Journal of Mathematics Teacher Education. Volume 7. Hal 145-172.

Sugiyono. (2013). Metode penelitian kuantitatif, kualitatif, dan $R \& D$. Bandung: Alfabeta.

Wardani \& Budiharti. (2014). Kajian Validitas Konstruk Modul IPA Terpadu Berbasis Scientific Approach Materi Pokok Suhu, Kalor dan Perpindahannya SMP Kelas VII. Jurnal Materi dan Pembelajaran Fisika (JMPF) 7 Kajian Validitas Konstruk Modul IPA Terpadu. Volume 4. No. 1, Hal. 7-12. 